\title{
82
} JOURNAL

\author{
Mariia LYZUN
}

\section{DEVELOPMENT TRENDS OF REGIONAL ECONOMIC INTEGRATION: METHODOLOGICAL ASPECT}

\begin{abstract}
The article investigates the transformation of approaches to understanding the processes of regional economic integration. The macro-region as a structural element of regionalism is explored. Criteria for typology of regional economic integration are systematized and divided into dichotomous and trichotomous. Factors influencing regional integration and current tendencies of its development are determined. A modern group of regional integration associations is identified, thus improving the existent typology. It includes regional and multilateral associations, hub and spoke regionalism, gravity agreements, plurilateral, bilateral, minilateral regionalism.
\end{abstract}

\section{Key words:}

Integration, regionalization, regionalism, macro-region, regional economic integration, multilateralism, regional economic arrangements, inter-regional interaction.

(C) Mariia Lyzun, 2020.

Lyzun Mariia, Doctor of Economic Sciences, Associate Professor, Professor at the Department of International Economics, Ternopil National Economic University, Ukraine. ORCID: https://orcid.org/ 0000-0003-3222-2962 Email: mlysun@ukr.net. 
JEL: F15, F13, F60, R10.

\section{Topicality of the research topic}

The processes currently occurring in the world economy, namely globalization, changing market conditions, increasing competition and the associated uncertainty of international economic and political relations, have led to the emergence of new imperatives of the mutual arrangement of states. Thus, economic integration is perhaps the most important process contributing to the sustainable development of the world's leading and developing countries. Regionally integrated territories, that is, those that meet both the criterion of concentration of more intensive economic relations between states and the criterion of institutional coordination on the basis of long-term common norms are becoming increasingly important. Among the main tasks of any form of regional integration are the expansion of mutual trade, elimination of obstacles to the free movement of capital flows, labour, industrial and scientific cooperation. These lead to an increase in economic growth, balance and sustainability of economic development. Effective regional integration enables the formation of a stable, supportive and predictable political environment, a fair distribution of forces in the world economy and equal opportunities for development.

\section{Ontology of regional economic integration processes}

In economic terminology, the word «integration» was first used in relation to the environment of industrial organizations when referring to business alliances of companies. These took various institutional forms, including that of a simple agreement, a cartel, a concern, a trust and, ultimately, merger and acquisition, where horizontal integration meant merging with competitors, while vertical - with suppliers and consumers (Machlup, 1977). The term «integration» (from the Latin Integrum - whole, integratio - restoration) is used in the broad sense of «uniting something into one" (Ukrainian Dictionary in 11 Volumes, 1973) and is widely used in economic, mathematical, engineering, sociological, biological sciences. The history of its application for denomination of state associations is relatively short. The 

methodological aspect

study by F. Machlup (1977) attempted to find the author who first used the term «economic integration» in its modern sense. It pointed to two independent sources: (1) a popular English translation of E. Heckscher's work Mercantilism made by M. Shapiro in 1935 . $^{1}$ (in the 1931 Swedish-language original, the author uses linguistically-dissimilar terms); (2) a lesser-known statistical analysis of German scientists H. Gaedicke and G. von Eynern Die produktionswirtschaftliche Integration Europas: Eine Untersuchung über die Aussenhandelsverflechtung der europäischen Länder of 1933. Interestingly, publications began to actively use the term «political integration» as early as the 1920s.

Variations of modern economic definitions of the term «integration» are shown in Table 1.

Specialized studies (especially western ones) usually refer to macrointegration in its functional context as simply economic integration, while its territorial dimension is called regional economic integration or regional integration. It is not realistic to divide the concept of functional and regional integration fully. Moreover, regional integration, with some approximation, can be seen as a subtype of functional integration implemented within narrow regional frameworks ${ }^{2}$. The opposing view of A. Bolaños (2016) is also true, which regards economic integration (along with political and physical) as a sub-type of the regional phenomenon.

Economists have not yet come to a consensus even on the definition of regional economic integration. For example, often the terms «regionalism», «regionalization», "regional (economic) integration» are used as absolute synonyms, although, in our opinion, there is a significant, primarily morphological, difference between them. In fact, regionalism is usually condensed to a deliberate effort on the part of the authorities (formal or informal) to build institutional cooperation between states in a particular geographical area (or, conversely, impede it). «Regionalization» is mostly understood as more spontaneous processes of intensification or reduction of commercial and social transactions in a particular geographical region, influenced by market factors. That is, de facto integration can exist without regionalism. It should also be noted that flows of goods and factors are often the most intense at the interregional level (Kang, 2016).

Regarding regional economic integration, we adhere the modern theoretical mainstream (Bolaños, 2016; Figuière, 2006; Kang, 2016), considering it as a simultaneous combination of upstream initiatives in the context of regionalization with the downstream strategic institutional measures that embody regionalism ${ }^{3}$.

\footnotetext{
${ }^{1}$ However, the term «disintegration» is used in the study.

${ }^{2}$ The assumption is not relevant for very broad or full integration cases.

${ }^{3}$ Studies that are more specialized sometimes consider a more detailed structure of regional economic integration. For example, A.Hurrell (1995) identifies 5 levels of regional cooperation / integration: (1) social and economic regionalization; (2) regional self-awareness and identity; (3) regional interstate cooperation; (4) state-initiated integration; (5) regional cohesion.
} 
Table 1

Range of economic definitions of the term «integration»

\begin{tabular}{|c|c|c|}
\hline \multicolumn{2}{|c|}{ Application options } & Economic definition of the category \\
\hline \multirow{8}{*}{ 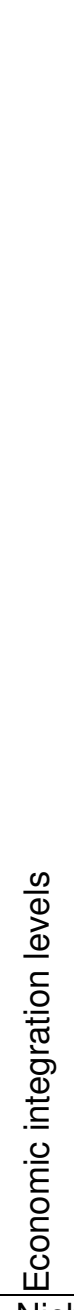 } & local integration & $\begin{array}{l}\text { Combining production process steps into one microeco- } \\
\text { nomic entity }\end{array}$ \\
\hline & $\begin{array}{c}\text { micro- } \\
\text { integration } \\
\text { (horizontal, ver- } \\
\text { tical, etc.) }\end{array}$ & $\begin{array}{l}\text { 1. Combining production process steps of a group of mi- } \\
\text { croeconomic entities; } \\
\text { 2. Mergers and acquisitions of the micro-entities within: } \\
\text { - one industry (horizontal integration); } \\
\text { - single production chain (up and down vertical inte- } \\
\text { gration); } \\
\text { distribution chain (non-production vertical integration } \\
\text { «up»); } \\
\text { - unrelated industries and production chains (integra- } \\
\text { tion based on ownership criteria). } \\
\text { All the sub-types of micro-integration discussed above } \\
\text { can be implemented at both national and international } \\
\text { (transnationalization) levels }\end{array}$ \\
\hline & $\begin{array}{l}\text { internal } \\
\text { meso-regional } \\
\text { integration }\end{array}$ & $\begin{array}{l}\text { Complex of associated economic entities in a certain re- } \\
\text { gion (area) within one country }\end{array}$ \\
\hline & $\begin{array}{l}\text { national inte- } \\
\text { gration }\end{array}$ & $\begin{array}{l}\text { Associated sectors of several regional c } \\
\text { state }\end{array}$ \\
\hline & $\begin{array}{l}\text { interstate } \\
\text { meso-regional } \\
\text { integration } \\
\text { (cross-border) }\end{array}$ & $\begin{array}{l}\text { Associated sectors of several regional complexes within } \\
\text { several bordering countries }\end{array}$ \\
\hline & $\begin{array}{c}\text { macro- } \\
\text { integration } \\
\text { (functional and } \\
\text { regional) }\end{array}$ & $\begin{array}{l}\text { 1. Combining or harmonizing economic sectors of sev- } \\
\text { eral countries regardless of geography (functional macro } \\
\text { integration); } \\
\text { 2. Combining or harmonizing economic sectors of sev- } \\
\text { eral countries within the framework of regional institutes } \\
\text { and norms }\end{array}$ \\
\hline & $\begin{array}{c}\text { mega- } \\
\text { integration }\end{array}$ & $\begin{array}{l}\text { Global economic space integration (including world eco- } \\
\text { nomic order) }\end{array}$ \\
\hline & \multicolumn{2}{|c|}{ Niche definitions: } \\
\hline \multicolumn{3}{|c|}{$\begin{array}{l}\text { Integration as a stage in the money laundering process whereby the funds are } \\
\text { returned to their owners after masquerading as legal operations }\end{array}$} \\
\hline
\end{tabular}

Source: systematized by the author. 


\section{Macro-region as a structural element of regionalism}

When interpreting the multifaceted term "(macro)region» ${ }^{4}$ we use the paradigm approach of new / comparative regionalism ${ }^{5}$. Within it, the broad definition of J. Nye (1971) is considered canonical «... a quantitatively limited group of countries that are geographically interconnected and share a degree of interdependence». That is, the category of «region» does not mean a specific geographically defined area (which can be very fragmented, as in the case of the European Free Trade Association (EFTA), or broad and inhomogeneous, as in the case of the Trans-Pacific Partnership (TTP)). Rather it is a dynamic qualitative description of the level of cooperation between states that position themselves together as a territorial alliance. A group of countries may be more or less a region (English literature uses the term «regionness» for this purpose). The key aspects of regional gradation, depending on the level of cohesion of its member states, are shown in Figure 1.

Regional arrangements can be considered a basic structural element of regionalism. They can be political, economic, military, etc. Among regional economic arrangements are:

- regional trade arrangements (RTA), which are the most massive alliances and, as they develop vertically, begin to encompass not only trade but virtually the entire spectrum of economic relations;

- regional monetary arrangements, which, depending on the interpretation, may include regional payments unions, co-financing agreements, examples of unilateral (dollarization) and collective (currency) unions of monetary integration, as well as historical forms of monetary and monetary systems, blocks and zones;

- regional financial arrangements, the typical representative of which is the recent European Stability Mechanism (in general, a group of regional financial institutions closely intertwine with monetary ones and it is not always possible to clearly differentiate between existing alliances).

\footnotetext{
${ }^{4}$ In the current context of globalization, of course, micro- and mesoregions also often have a cross-border determinant.

${ }^{5}$ In its categorical plane there is a whole theoretical direction called «regionhood», within which the determination and classification of different types of regions is carried out (Van Langenhove, 2003).
} 
Fig. 1

Macro-region features depending on the level of cohesion ${ }^{6}$

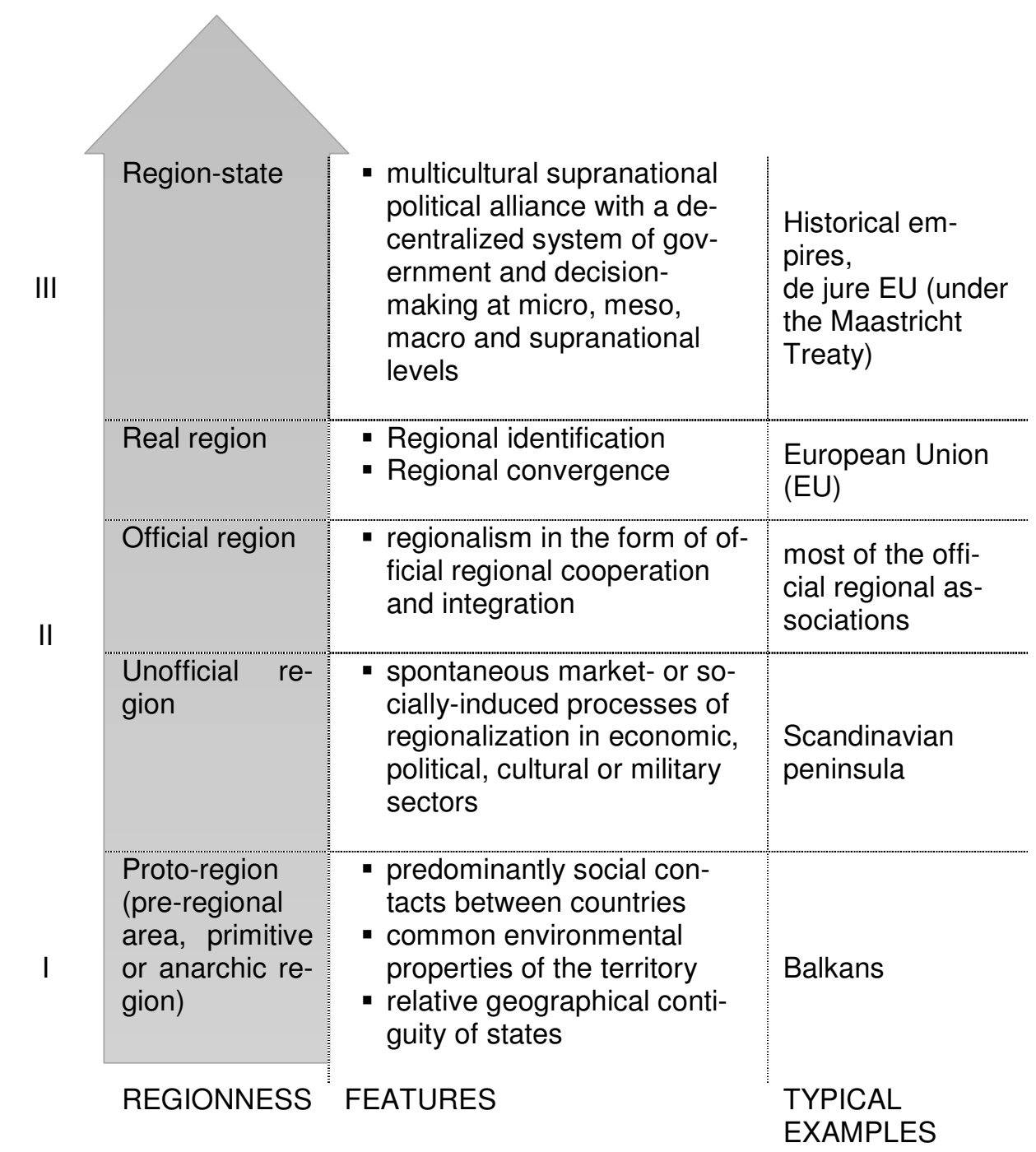

Source: author's visualisation based on Hurrell (1995), Keating (1998), Söderbaum (2003)

\footnotetext{
${ }^{6}$ Basic architecture. For a more detailed overview of the category with some alternative levels, see Hettne (2003).
} 


\section{Criteria for typology of regional economic integration}

The growing diversity of regional arrangements in terms of institutional support, tactical tools and ideology has led to attempts of modernising their typology. New complementary approaches are emerging that attempt to organize territorial alliances from different perspectives. Such approaches can be roughly divided into dichotomous and trichotomous, depending on the number of determinant criteria.

The main dichotomous criteria are shown in Table 2. The first and foremost criterion is the level of actual effectiveness of regional integration, which can be determined by estimating the share of intra-regional trade in total exports and imports. For example, the share of intra-regional trade in the EU exceeds $60 \%$, while in the West African Economic and Monetary Union (WAEMU) it does not reach 10\% (Kang, 2016). On the other hand, in the 1990s, even before the start of institutional regionalism, Eastern Asian states demonstrated a high intensity of mutual commodity and investment flows even without any preferential trade regimes, which again raises the question of the overall effectiveness of regionalism in principle.

Table 2

Dichotomous criteria for the typology of regional economic integration

\begin{tabular}{|l|l|l|}
\hline \multicolumn{1}{|c|}{ Criterion } & \multicolumn{2}{c|}{ Integration type } \\
\hline 1. Effectiveness level & De-jure integration & De-facto integration \\
\hline 2. Openness & Closed integration & Open regionalism \\
\hline $\begin{array}{l}\text { 3. Level of integration not ac- } \\
\text { counting trade liberalization }\end{array}$ & Shallow integration & deep \\
\hline
\end{tabular}

Source: author's modification of Kang Y. D. (2016)

The openness criterion of membership in an integration association determines the difference between closed and open regionalism. When we talk about closed regionalism, we are referring not so much to the prohibitions or minimum requirements for membership in the alliance, as to the relationship between the integration association and the rest of the world. The first examples of closed regionalism began to function in Latin America and Africa during the 1960s as at- 
tempts to expand restricted domestic markets through import substitution policies and simultaneous promotion of intra-regional production. However, such peculiar attempts at intra-regional autarchy and exclusion from international markets were not very effective. First, preferential trade liberalization concerned a very limited set of goods that could not result in a significant increase in trade. Second, because of the import substitution policy for regional production, less industrialized association members essentially supported the underperforming industries of their relatively more industrialized neighbours. And third, if preferential liberalization could weaken the position of local oligarchic producers with powerful lobbies in governments, then negotiations to mitigate tariffs or non-tariff measures between partners were usually deadlocked.

The conceptual framework of open regionalism has not yet been developed particularly comprehensively. According to F. Bergsten (1997), an open regional association must be characterized by at least one of these three features:

- a trade block created on the basis of free membership and, in the case of popularity, institutionally reorganized into a free trade area;

- an already closed regional association adopts the most-favoured nation treatment to the rest of the world;

- an intergovernmental arrangement that uses the principles of consensus in the decision-making process to solve common problems and converge state policy initiatives around a particular model.

The Asia-Pacific Economic Cooperation (APEC) is sometimes called the empirical embodiment of this model (Webber, 2001), however, is difficult to consider this association an expression of regionalism since it bears no regional contractual content.

In this regard, we must also mention the opinion of C. Deblock (2005), who believes that the foundations of open regionalism were formed in the late 1980s in the form of support for a multilateral trading system. That is, an increase in the number of RTAs can be seen as a tendency to form fragmented multilateralism, and regionalism is an obstacle to this progress.

The third dichotomous criterion concerns the depth of the integration process. Researchers are less trying to clearly distinguish between the stages of regional integration a la B. Balassa, and instead use the generalized division of «shallow» integration and «deep» integration. The «shallow» characteristic refers to associations in which integration is manifested solely in the form of dismantlement of trade barriers (including partial agreements), while regulation of capital flows, monetary or financial harmonization are found only in declarations of intent. Deep integration, however, implies the presence of certain features (though perhaps not fully formed) of a common market or a monetary union. For example, the term "customs and monetary union» used to denominate Africa's cur- 
rency blocs (which, though not always meet the formal criteria of the customs union, do use common currency), has become quite a staple.

A trichotomous typology of regional integration in different variations was proposed by a number of French researchers (Deblock, 2005) who were inspired by the incompatibility trilogy (the so-called «blessed trinity»), stemming from the Mundell-Fleming model. An aggregate version of two trichotomous models with similar principles but different perspectives is shown in Fig. 2.

Fig. 2

\section{Trichotomous typology of regional integration}

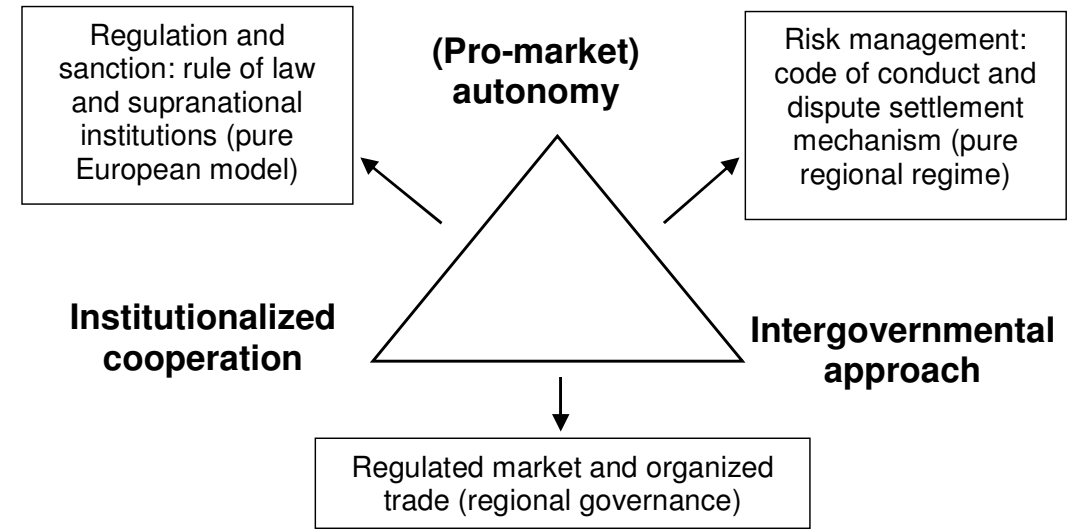

Source: Deblock C. (2005).

The angles of the model reflect the features of regionalism, which are compatible only in two "neighbouring" combinations: (pro-market) autonomy; sovereignty of members (intergovernmental approach) and institutionalized cooperation. Regionalism in such dimensions can be based on three fundamental principles (only two of which are economic):

1. Regulation and sanction - a type of regionalism based on a marketbased approach with a rigid institutional framework and a supranational entity (the EU is a typical example);

2. Risk management - regionalism based on market mechanisms with a high level of sovereignty between members of an association (e. g. NAFTA); 
3. Regionalism based on administrative non-market regulation (the Soviet Union is an example from the past).

The trichotomous typology has become an original example of the regionalism typology, especially given its emphasis on deep integration. However, it also has some drawbacks. First, the trichotomous model overlooks the regional dimension; dialectical contradictions between regionalism and multilateralism, regionalism and globalization are not outlined. Second, integration between countries with different levels of development (North-South relations) is not taken into account. In addition, it does not take into account the fact that one state can be a member of several groups with different partners at the same time, i.e., defacto one regional group facilitates the emergence of other regional groups. Moreover, in our opinion, the very methodological basis of the trichotomous model is somewhat doubtful - the true degree of incompatibility of the proposed dimensions of the «incompatible triangle» is not completely clear (we believe that the EU simultaneously meets all three criteria).

\section{Factors influencing regional integration and patterns of its development}

Since 2000, regional integration processes have reached unprecedented complexity and variability. None of the above typologies is able to substantiate their diversity fully.

The key factors that determine the face of contemporary regionalism are quite diverse. Thus, the scientific debate on the interplay of multilateralism and regionalism can be summarised in two key questions. The first one concerns the nature and direction of the influence that preferential trade liberalization within regional blocs has on the general trend towards the progress or regression of the multilateral system. That is, whether the ambiguous role of regionalism is a cornerstone or, conversely, a stumbling block to the unification and liberalization of world trade. The scientific substantiation of the positive effect of regionalism is found in the writings of L. Summers (1991), R. Z. Lawrence (2000), and R. Baldwin (1993); while among the sceptics are J. N. Bhagwati (1995), A. Panagariya (1999), and A. O. Krueger (1993).

The second, somewhat less controversial question is how the development of multilateral trading systems affects the intensity of regionalism. This aspect is true for both developed and developing countries and is closely linked to the preference margin of regionalism. While considering this issue, the speculative hypothesis is the starting point: if multilateral trade liberalization brings satisfactory results to states, then the desire to initiate regionalism should diminish. 

methodological aspect

However, delays or lack of consensus in multilateral trade negotiations can make regionalism more attractive.

Globalization of the economy is the second external factor affecting the processes of regional integration, and it can manifest itself in three aspects. First, the main manifestation of globalization is the growth of international trade and the increased mobility of production factors, which are relatively regionally determined, as geographical distance continues to be an important element in determining the value of a product. That is, these are processes of regionalization that, on an ascending principle, determine the geography of regionalism and, potentially, may be the first phase of «total globalization».

In the context of the simultaneous functioning and interaction of different regional blocks, a number of motivational effects can be distinguished:

- threat effect, which encourages states left behind by the integration and other regional blocs to either create their own associations or intensify existing ones;

- demonstration effect, through which successful models of regional alliances find new implementation in other regions.

On the European continent, the manifestation of the threat effect can be clearly traced: the creation of the European Free Trade Association was largely motivated by fears of discrimination among states that did not join the European Economic Community (Baldwin, 1994). Moreover, the EFTA completed internal liberalization of trade even faster than the EEC, which, however, did not save it from the loss of almost half of the members (Great Britain, Ireland, Denmark, and in the long term, most likely Iceland, which have gradually transitioned to the EEC / EU). The success of the EEC has also provoked a demonstration effect for the rest of the world. In particular, it can be traced in the Latin American countries that created the Latin American Free Trade Association in the 1960s to intensify cooperation and increase political weight in the world.

Another effect of intensification of interregional interaction is more structural in nature and manifests in the formation of the so-called «hub and spoke» regionalism, which is the reason for the rapid growth (proliferation) of regional blocs. By hub and spoke regionalism, we mean the model of an association with an explicit central leader-state, which is the nexus of all trade and production ties of the integration alliance (relations between non-central powers, denominated as spokes emanating from one centre in the model, are not significant). Once the hub and spoke model of the regional bloc has set, it becomes difficult for spokestates to redirect capital flows to their own advantage and achieve significant market volume growth. A possible way out of this situation is forming a new regional bloc with other spoke-states, which due to the domino effect leads to the proliferation of regional blocs. It is worth noting that, since the early 1990s, two global regional hubs have emerged in the world - the EU and NAFTA - that have 
forced other nations to worry about their own relegation to the status of a "spoke» and to launch processes of regionalism around the world (particularly in Asia).

The second group of factors that influence the activities of modern regional integration blocks is determined by the number of participants in the association. Formally, a regional association with more than two participants is called plurilateral. Initially, such associations originated between neighbouring countries and often aimed at creating a regional market with a deep level of integration.

Since the 2010s, a new type of plurilateral alliances has been emerging the so-called mega-regional associations. Their distinctive feature is the geographical remoteness of member states and the existence of numerous bilateral or multilateral agreements already in place between them. That is, mega-regional associations are an attempt to combine an array of more «local» alliances into one package, thereby eliminating the «spaghetti bowl effect» ${ }^{7}$. Excessive regulatory entanglement of bilateral agreements has become a real problem - according to research (Kawai, 2009), less than a third of Asian entrepreneurs make effective use of preferential foreign trade regimes. Another important point of the mega-regional blocs is the involvement of less developed countries, thus contributing to the regulatory convergence between the North and the South. Admittedly, the blurry regional identity gives grounds to speak of mega-regionalism as a category of commercial policy rather than politically motivated regional integration.

One more tendency can be distinguished in the context of the modern plurilateral alliances, which C. Brummer (2014), in contrast to multilateralism, calls «minilateralism». Minilateral trade alliances are created on the basis of informal or «soft law» agreements and financial schemes aimed at liberalizing relations between members of the association.

An important aspect of modern regionalism is the emergence of a system of gravity trade agreements involving two parties: a trade bloc and a non-bloc country. With the help of gravity agreements, the trade bloc strengthens its position as a regional hub, while the non-bloc state gains better access to markets and increases its attractiveness as an FDI recipient. Gravity agreements should be distinguished from bilateral partnerships with other regional associations or large economies. Thus, considering the numerous European Union cooperation agreements, several types can be identified. Among them: the European Economic Area (agreement with the EFTA without Switzerland); Customs Union (Andorra, Monaco, San Marino, Turkey); different types of Association Agreements such as Stabilisation Agreements (with members of the Central European Free Trade Area, CEFTA), Deep and Comprehensive Free Trade Areas (including the partially implemented one with Ukraine); classic bilateral free trade zones;

\footnotetext{
7 The term was first introduced by J. Bhagwati (1995). An adaptation is applied when discussing the Asian region: «noodle bowl effect».
} 
systems of non-reciprocal preferences, and so on. Only a small proportion of regional agreements that EU is involved in, can be called gravity agreements (including association agreements and bilateral free zones).

The global financial crisis of 2008-2009 has affected not only the global economy, but also the intensity of regionalism. In trying to make up for the lack of regulation in the pre-crisis decade, governments began to consider the possibility of strengthening protectionism, which led to the suspension or delay of integration initiatives.

At the same time, the global crisis contributed to the reshaping of the trading landscape and gave impetus to the creation of new bilateral and regional blocs with a focus primarily on their economic efficiency rather than diplomatic «attractiveness» (e.g., mega-regional alliances). An additional motivation is also the fact that in the context of economic turmoil, there is a greater possibility of implementing even politically unattractive reforms.

In addition, crisis events often enhance cooperation between neighbouring countries as the spill-over effect of regional public goods is reviewed. Researchers often note that the 1999 Asian financial crisis gave impetus to East Asian regionalism (Bustelo, 2003; Lee, 2012), although before that the territory was determined almost exclusively by processes of regionalization. Thus, while only three FTAs operated in the region in 2000, ten years later 37 FTAs were launched and negotiations were underway on 72 more, which led to the emergence of a «noodle bowl effect».

In addition to the Asian region, in the post-crisis period, two «whales» of the modern economy began to exhibit hyperactivity in the formation of regional structures: the EU (the so-called Global European Initiative) and the US. Today's regional associations are increasingly incorporating regulatory considerations. Researchers note (Bown, 2017; Horn, 2010) that both the US and the EU have made considerable efforts to fragment the WTO-sponsored multilateral world into smaller blocks that can be grouped into:

- WTO+ - associations that, in addition to tariff liberalization under multilateralism, offer even more preferential terms for trading partners, however, only for members of the alliance;

- WTO- $X$ - associations that, in addition to trade liberalization, have additional regulatory obligations, such as labour market or environmental standards.

Both types of norm-generating arrangements that include EU and US are sometimes referred to as «hegemonic multilateralisation of trading principles» (Hoekman, 2007). 


\section{Conclusions}

Integration processes are one of the determining factors that shape the general outlines of the modern geo-economic and geopolitical map of the world. The theory of regional economic integration is characterized by the increased attention of scientists in all fields of economic sciences. At the same time, there are significant conceptual differences between different scientific schools (and often within the same school), in particular regarding the interpretation of the terms «regionalism», «regionalization», «regional (economic) integration».

Regional economic integration is a simultaneous combination of the spontaneous processes of intensification or reduction of commercial and social transactions in a particular geographic region under the influence of market factors (regionalization) and the downward strategic institutional measures of the formal and informal authorities to reorganize mutual relations between states in geopolitical space (regionalism).

Regional trade arrangements can be considered the basic structural element of regionalism and regionalization. While the classification of the forms of RTAs proposed by B. Balassa in the 1960 s was ahead of its time, it is gradually losing its relevance. Transformation processes occurring in the global economy have made it possible to identify a group of modern types of regional integration arrangements: multilateral, hub and spoke, plurilateral, gravity, bilateral regional and minilateral agreements.

\section{Acknowledgements}

This work was supported by the Erasmus+ program of the European Union (Jean Monnet Module 612067-EPP-1-UA-EPPJMO-MODULE «European Regional Policy: Balance of Local, National and Pan-European Interests»). The European Commission support for the publication of this article does not constitute an endorsement of the contents, which reflects the views of the authors only, and the Commission cannot be held responsible for any use, which may be made of the information contained therein. 


\section{References}

1. Baldwin R. (1993). A domino theory of regionalism. National Bureau of Economic Research.

2. Baldwin R. (1994). Towards an Integrated Europe. Centre for Economic Policy Research.

3. Bergsten C. (1997). Open regionalism. Whither APEC: The Progress to Date and Agenda for the Future, pp. 545-565.

4. Bhagwati J. (1995). US Trade Policy: The Infatuation with FTAs. Columbia University, Department of Economics.

5. Bolaños A. (2016). A Step Further in the Theory of Regional Integration: A Look at the Unasur's Integration Strategy. SSRN Scholarly Paper ID 2780799. Rochester, NY. Social Science Research Network.

6. Bown C.P. (2017). Mega - Regional Trade Agreements and the Future of the WTO. Global Policy, 8(1), pp. 107-112.

7. Brummer C. (2014). Minilateralism: How Trade Alliances, Soft Law and Financial Engineering are Redefining Economic Statecraft. Cambridge University Press.

8. Bustelo P. (2003). The Impact of the Financial Crises on East Asian Regionalism. Regionalism in East Asia: paradigm shifting.

9. Deblock C. (2005). Economic regionalism and globalization: what do theories teach us? Cahier de recherche, 5(7). (in French)

10. Figuière, C., Guilhot L. (2006). Characterizing regional processes: the contributions of an approach in terms of coordination. Mondes en développement, 3, pp. 79-100. (in French).

11. Gaedicke H., von Eynern G. (1933). European integration in production: an analysis of foreign trade integration of the European countries. 2nd Vol. Junker u. Dünnhaupt. (in German).

12. Heckscher E.F. (1955). Mercantilism (translated from the Swedish by Mendel Shapiro). rev. ed., London. Allen \& Unwin.

13. Hettne B. (2003). The new regionalism revisited. Theories of new regionalism. Palgrave Macmillan, London, pp. 22-42

14. Hoekman B., Winters L. A. (2007). Multilateralizing «Deep Regional Integration»: A Developing Country Perspective. Conference on Multilateralizing Regionalism, WTO and CEPR, pp. 10-12. 
15. Horn H., Mavroidis P. C., Sapir A. (2010). Beyond the WTO? An anatomy of EU and US preferential trade agreements. The World Economy, 33(11), pp. 1565-1588.

16. Hurrell A. (1995). Regionalism in theoretical perspective. Regionalism in world politics: Regional organization and international order, pp. 37-73.

17. Kang Y. D. (2016). Development of regionalism: new criteria and typology. Journal of Economic Integration, pp. 234-274.

18. Kawai M., Wignaraja G. (2009). The Asian «noodle bowl»: Is it serious for business. Asian Development Bank Institute (ADBI) Working Paper Series, 136.

19. Keating M. (1998). The new regionalism in Western Europe: territorial restructuring and political change. Cheltenham, UK: E. Elgar.

20. Krueger A.O. (1993). Free trade agreements as protectionist devices: Rules of origin. National Bureau of Economic Research.

21. Lawrence R.Z. (2000). Regionalism, multilateralism, and deeper integration. Brookings Institution Press.

22. Lee S. (2012). The evolutionary dynamics of institutional balancing in East Asia. 2012. Retrieved from: http://eai.or.kr/data/bbs/eng_report/20120209104282.pdf.

23. Lishchynskyy I. (2019). Poles and axes of development in the context of glocalization processes. Monograph. Ternopil: TNEU, 364 p. (in Ukrainian).

24. Lyzun M. (2017). Architecture of modern processes of regional integration. Economy and Society, 13, pp.102-107. (in Ukrainian).

25. Lyzun M. (2017). Global challenges of regional monetary integration. Monograph. Ternopil: Economic Thought, 426 p. (in Ukrainian).

26. Lyzun M., Lishchynskyy I. (2019). Trends in the development of regional and multilateral monetary integration. Problems of Systemic Approach in the Economy, 1(69), pp. 52-58. (in Ukrainian).

27. Machlup F. (1977). A History of Thought on Economic Integration. Palgrave Macmillan UK.

28. Nye J.S. (1971). Peace in Parts: Integration and Conflict in Regional Organization. Little, Brown.

29. Panagariya A. (1999). The regionalism debate: an overview. The World Economy, 22(4), pp. 455-476.

30. Söderbaum F., Shaw T.M. (2003). Theories of New Regionalism: A Palgrave Reader. Palgrave Macmillan UK.

31. Summers L. (1991). Regionalism and the world trading system. Policy implications of trade and currency zones, pp. 295-301. 
32. Ukrainian Dictionary in 11 Volumes. (1973). Integration. Vol. 4 (35). (in Ukrainian).

33. Van Langenhove L. (2003). Theorising Regionhood. United Nations University Comparative Regional Integration Studies.

34. Webber D. (2001). Two funerals and a wedding? The ups and downs of regionalism in East Asia and Asia-Pacific after the Asian crisis. The Pacific Review, 14(3), pp. 339-372. 